\title{
Chemotherapy and other Factors Affecting Quality of Life in Non-Small Cell Lung Cancer (NSCLC) Patients
}

\author{
LAURA MAZILU1', DANA LUCIA STANCULEANU ${ }^{2}$, ANDREEA DANIELA GHEORGHE ${ }^{1}$, ADRIAN PAUL SUCEVEANU1, \\ IRINEL RALUCA PAREPA ${ }^{1}$, ANCA PANTEA STOIAN²*, CORINA SILVIA POP², OVIDIU BRATU², ANDRA IULIA SUCEVEANU ${ }^{1}$ \\ ${ }^{1}$ Ovidius University, Faculty of Medicine, Universitatii Str., 900470, Constanta, Romania \\ ${ }^{2}$ Carol Davila University of Medicine and Pharmacy, 8 Eroii Sanitari Str., 050474, Bucharest, Romania
}

\begin{abstract}
NSCLC accounts around $80 \%$ of all lung cancers. NSCLC patients have usually a lousy quality of life (QoL), influenced by the malignant disease itself and by cancer treatment modalities. We conducted an observational study in Oncology Department, Clinical Emergency Hospital, Constanta, on a sample of 50 patients diagnosed with NSCLC one year. Our study data showed that younger patients have a better QoL regarding social/family well-being, but withoutother significant differences. Also, patients living in the urban area have a better QoL regarding social/family well-being. Patients having better performance status obtain higher scores from all subscales of the FACT- $G$ questionnaire and, also a higher FACT-G total scale, these results are showing that better the performance status and general status of the patient, better the QoL. We detected a significant relationship between $\mathrm{QoL}$ and disease stage or presence of metastasis. We found no clinical significance between QoL scores with respect with chemotherapy protocol or the number of cycles of chemotherapy. We aimed to show that factors influencing the QoL of NSCLC patients are stage of the disease and performance status of the patients. To diminish the negative impact, one important step in ameliorating the QoL of NSCLC patients is to detectall factors influencing it and offer psychological spiritual and social support.
\end{abstract}

Keywords: quality of life, non small cell lung cancer

NSCLC accounts around $80 \%$ of all lung cancers. In majority of cases, the late diagnosis is equal with advanced disease [1].

With the advanced of therapeutic methods and the improvement of survival rates, the question of how to increase the quality of life (QOL) of NSCLC patients raise. QoL of patients with NSCLC is influenced by both the malignant disease and cancer treatment modalities [2-4]. The beginning of QoL concept goes to 1947, when World Health Organization defined health as state of complete physical, mental and social well-being, and not merely the absence of disease and infirmity [5]. The first QoL measurement is Spitzer's QL-Index, and it is based on the notion that measures of QOL should include physical, social, and emotional function, the attitude of the patients to disease, personal features of patients, including family and friends interactions; and the financial burden of the disease [6].

QoL looks to be an important predictive factor of survival in NSCLC patients. The assessment of factors influencing the QoL may lead to better management of the disease. QoL in lung cancer patients depends on tumor localization, stage, treatment, and prognosis, being always influenced by symptoms. Common complains as loss of appetite, dyspnea, cough, pain, fatigue, may the lower QoL according to severity $[3,7]$.

\section{Experimental part \\ Methods}

We conducted an observational descriptive study in Oncology Department of Clinical Emergency Hospital of Constanta, on 50 patients diagnosed with NSCL in a period of one year, from 2017 to 2018. All our patients could understand English. They understood objectives of this study and they were informed about privacy or confidentiality, and signed informed consent was obtained from all participants. Personal and medical information of the patients were obtained using medical records. Medical staff filled the questionnaire during an interview with the patients. Written permission was obtained to use the FACTG scale.

Patient information included information about demographics, cancer diagnosis and stage, treatment and side effects. Performance status of the patients was performed using the Eastern Cooperative Oncology Group (ECOG). QoL was assessed using Functional Assessment of Chronic Therapy-General (FACT-G) version 4.0. This scale is using 27 items that measure emotional well-being (EWB), physical well-being (PWB), functional well-being (FWB) and social/family well-being (SWB). Each item has five possibilities of responses, noted from 0 to 4 , scoring from not at all to very much. FACT-G total score is calculated by summing the subscales scores, and the result is a score ranging from 0 to 108 [8-10]. Higher the FACT-G score means better QoL.

Statistical Package for the Social Sciences version 20.0 software (SPSS) was used for results analyze.

\section{Results and discussions}

The total group of patients in our study comprises of 50 patients diagnosed with NSCLC. Patients general characteristics and disease features are described in Table no. $1.78 .0 \%$ of patients were represented by male gender while $22.0 \%$ were represented by the female gender. Median age was $62.86 \pm 7.48$, ranging from 41 to 82 years. $88.0 \%$ of patients were smokers. Most of NSCLC were squamous cell carcinoma type, followed by adenocarcinomas. Most of the patients had advanced disease at the time of diagnosis, mostly stages III and IV. The performance status was good for our patients, in general.

Comparison between patient's characteristics and FACT$G$ score was done using SPSS v20.0; $P$ values $<0.05$ are 
Table 2

Table 1

CHARACTERISTICS OF PATIENTS

\begin{tabular}{|c|c|}
\hline Characteristics & $\begin{array}{l}\text { No of patients } \\
\text { (total=50), \% }\end{array}$ \\
\hline $\begin{array}{l}\text { Age (years) } \\
\text { Median } \\
\text { Range } \\
\leq 60 \text { years } \\
\geq 61 \text { years }\end{array}$ & $\begin{array}{l}62.86 \pm 7.48 \\
41-82 \\
21(42.0 \%) \\
29(58.0 \%)\end{array}$ \\
\hline $\begin{array}{l}\text { gender } \\
\text { Female } \\
\text { Male }\end{array}$ & $\begin{array}{l}11(22.0 \%) \\
39(78.0 \%)\end{array}$ \\
\hline $\begin{array}{l}\text { Provenience } \\
\text { Urban } \\
\text { Rural }\end{array}$ & $\begin{array}{l}30(60.0 \%) \\
20(40.0 \%)\end{array}$ \\
\hline $\begin{array}{l}\text { Smoking } \\
\text { Non-smokers } \\
\text { Smokers }\end{array}$ & $\begin{array}{l}6(12.0 \%) \\
44(88.0 \%)\end{array}$ \\
\hline $\begin{array}{l}\text { Histopathological type } \\
\text { Adenocarcinoma } \\
\text { Squamous } \\
\text { Other }\end{array}$ & $\begin{array}{l}22(44.0 \%) \\
25(50.0 \%) \\
3(6.0 \%) \\
\end{array}$ \\
\hline $\begin{array}{l}\text { Stage of the disease } \\
\text { II } \\
\text { III } \\
\text { IV }\end{array}$ & $\begin{array}{l}4(8.0 \%) \\
22(44.0 \%) \\
24(48.0 \%) \\
\end{array}$ \\
\hline $\begin{array}{l}\text { Surgery } \\
\text { Yes } \\
\text { No }\end{array}$ & $\begin{array}{l}7(14.0 \%) \\
43(86.0 \%)\end{array}$ \\
\hline $\begin{array}{l}\text { Radiotherapy } \\
\text { Yes } \\
\text { No }\end{array}$ & $\begin{array}{l}11(22.0 \%) \\
39(78.0 \%)\end{array}$ \\
\hline $\begin{array}{l}\text { ECOG } \\
0 \\
1 \\
2 \\
3 \\
\end{array}$ & $\begin{array}{l}19(38.0 \%) \\
14(28.0 \%) \\
9(18.0 \%) \\
8(16.0 \%)\end{array}$ \\
\hline $\begin{array}{l}\text { Cycles of chemotherapy } \\
\leq 5 \\
\geq 6\end{array}$ & $\begin{array}{l}14(28.0 \%) \\
36(82.0 \%)\end{array}$ \\
\hline $\begin{array}{l}\text { Chemotherapy agents } \\
\text { Platinum-based } \\
\text { Non-platinum based }\end{array}$ & $\begin{array}{l}32(64.0 \%) \\
18(36.0 \%)\end{array}$ \\
\hline
\end{tabular}

considered statistically significant. All data is recorded in table 2.

Statistical analysis showed no significant differences in QoL scores between genders. Our data study showed that younger patients have a better $\mathrm{Q}$ oL regarding social/family well-being, but without other significant difference according to age. Also, patients living in the urban environment had a better QoL regarding social/family wellbeing $(p<0.05)$. No difference was found in QoL between smokers and non-smokers population.

Better performance status was associated with higher scores from all FACT-G subscales and FACT-G total scale; this result is showing that better the performance status and general status of the patient, better the QoL.

We also observed a significant relationship between QoL and stage of the disease and the presence of metastasis. Advanced disease, stages III or IV, were accompanied by lower scores than earlier stages[11]. Regarding treatment, no notable clinical difference was found in FACT-G score in patients receiving chemotherapy
COMPARISON OF FACT-G SCORE WITH PATIENTS CHARACTERISTICS

\begin{tabular}{|c|c|c|c|c|c|}
\hline Patients & PWB (mean) & $\begin{array}{l}\text { SWB } \\
\text { (mean) }\end{array}$ & $\begin{array}{l}\text { EWB } \\
\text { (mean) }\end{array}$ & $\begin{array}{l}\text { FWB } \\
\text { (mean) }\end{array}$ & $\begin{array}{l}\text { FACT } \\
\text { G total }\end{array}$ \\
\hline $\begin{array}{l}\text { Gender } \\
\text { Female } \\
\text { Male }\end{array}$ & $\begin{array}{l}14.64 \\
11.85 \\
P=0.184\end{array}$ & $\begin{array}{l}17.27 \\
16.92 \\
P=0.79\end{array}$ & $\begin{array}{l}11.64 \\
10.74 \\
P=0.89\end{array}$ & $\begin{array}{l}11.45 \\
14.08 \\
P=0.06\end{array}$ & $\begin{array}{l}55.0 \\
53.59 \\
P=0.50\end{array}$ \\
\hline $\begin{array}{l}\text { Age } \\
\leq 60 \text { years } \\
\geq 61 \text { years }\end{array}$ & $\begin{array}{l}13.47 \\
12.79 \\
P=0.24\end{array}$ & $\begin{array}{l}17.42 \\
15.43 \\
P<0.05\end{array}$ & $\begin{array}{l}11.60 \\
10.67 \\
P=0.19\end{array}$ & $\begin{array}{l}13.84 \\
12.87 \\
P=0.24\end{array}$ & $\begin{array}{l}55.60 \\
49.42 \\
P=0.22\end{array}$ \\
\hline $\begin{array}{l}\text { Area } \\
\text { Urban } \\
\text { Rural }\end{array}$ & $\begin{array}{l}11.10 \\
13.37 \\
P=0.203\end{array}$ & $\begin{array}{l}18.40 \\
16.07 \\
P=0.03\end{array}$ & $\begin{array}{l}11.10 \\
10.83 \\
P=0.77\end{array}$ & $\begin{array}{l}14.40 \\
12.90 \\
P=0.20\end{array}$ & $\begin{array}{l}55.0 \\
53.17 \\
P=0.30\end{array}$ \\
\hline $\begin{array}{l}\text { Smoking } \\
\text { Non-smokers } \\
\text { Smokers }\end{array}$ & $\begin{array}{l}14.83 \\
12.14 \\
P=0.316\end{array}$ & $\begin{array}{l}17.50 \\
16.93 \\
P=0.73\end{array}$ & $\begin{array}{l}10.50 \\
11.00 \\
P=0.71\end{array}$ & $\begin{array}{l}11.33 \\
13.80 \\
P=0.17\end{array}$ & $\begin{array}{l}54.17 \\
53.86 \\
P=0.91\end{array}$ \\
\hline $\begin{array}{l}\text { Stage of the } \\
\text { disease } \\
\Pi^{a} \\
I^{a} \\
I^{b} \\
I^{c}\end{array}$ & $\begin{array}{l}14.90 \\
10.80 \\
10.00 \\
P<0.05 \\
a>b, c\end{array}$ & $\begin{array}{l}17.48 \\
16.52 \\
16.50 \\
P<0.05 \\
a>b, c\end{array}$ & $\begin{array}{l}14.90 \\
10.40 \\
6.50 \\
P<0.05 \\
a>b>c\end{array}$ & $\begin{array}{l}14.60 \\
13.75 \\
12.14 \\
P<0.05 \\
a>b>c\end{array}$ & $\begin{array}{l}56.00 \\
53.20 \\
46.75 \\
P<0.05 \\
a, b>c\end{array}$ \\
\hline $\begin{array}{l}\text { Surgery } \\
\text { Yes } \\
\text { No }\end{array}$ & $\begin{array}{l}12.95 \\
9.57 \\
P=1.83\end{array}$ & $\begin{array}{l}16.57 \\
16.98 \\
P=0.80\end{array}$ & $\begin{array}{l}6.86 \\
11.64 \\
P<0.05\end{array}$ & $\begin{array}{l}14.00 \\
13.26 \\
P=0.65\end{array}$ & $\begin{array}{l}47.00 \\
54.83 \\
P=0.05\end{array}$ \\
\hline $\begin{array}{l}\text { Radiotherapy } \\
\text { Yes } \\
\text { No }\end{array}$ & $\begin{array}{l}12.55 \\
12.44 \\
P=0.95\end{array}$ & $\begin{array}{l}18.18 \\
16.67 \\
P=0.25\end{array}$ & $\begin{array}{l}10.64 \\
11.03 \\
P=0.71\end{array}$ & $\begin{array}{l}12.91 \\
13.67 \\
P=0.59\end{array}$ & $\begin{array}{l}54.27 \\
53.79 \\
P=0.85\end{array}$ \\
\hline $\begin{array}{l}\text { ECOG } \\
0 \\
1 \\
2 \\
3\end{array}$ & $\begin{array}{l}21.92 \\
15.23 \\
9.21 \\
4.20 \\
P<0.05 \\
\end{array}$ & $\begin{array}{l}21.20 \\
17.38 \\
14.32 \\
12.42 \\
P<0.05 \\
\end{array}$ & $\begin{array}{l}14.32 \\
12.73 \\
7.75 \\
4.10 \\
P<0.05 \\
\end{array}$ & $\begin{array}{l}19.60 \\
15.42 \\
9.62 \\
4.89 \\
P=0.05 \\
\end{array}$ & $\begin{array}{l}73.80 \\
59.64 \\
39.86 \\
24.40 \\
P=0.05\end{array}$ \\
\hline $\begin{array}{l}\text { Cycles of } \\
\text { chemotherapy } \\
\leq 5 \\
\geq 6\end{array}$ & $\begin{array}{l}12.79 \\
12.24 \\
P=0.56\end{array}$ & $\begin{array}{l}17.20 \\
17.44 \\
P=0.78\end{array}$ & $\begin{array}{l}10.35 \\
10.68 \\
P=0.47\end{array}$ & $\begin{array}{l}11.88 \\
11.84 \\
P=0.60\end{array}$ & $\begin{array}{l}52.80 \\
51.36 \\
P=0.82\end{array}$ \\
\hline $\begin{array}{l}\text { Chemotherapy } \\
\text { agents } \\
\text { Platinum-based } \\
\text { Non-platinum } \\
\text { based }\end{array}$ & $\begin{array}{l}14.08 \\
12.22 \\
P=0.33\end{array}$ & $\begin{array}{l}16.38 \\
17.78 \\
P=0.25\end{array}$ & $\begin{array}{l}11.08 \\
11.28 \\
P=0.85\end{array}$ & $\begin{array}{l}12.58 \\
14.11 \\
P=0.26\end{array}$ & $\begin{array}{l}54.13 \\
\\
55.39 \\
P=0.51\end{array}$ \\
\hline
\end{tabular}

or radiotherapy, no matter of protocols used or the number of chemotherapy cycles, while patients with limited disease undergoing surgery had important improvement in emotional well-being subscale score and FACT-G total score.

Incidence and mortality related to NSCLC are still very high worldwide. The majority of NSCLC patients present themselves with advance stages affecting the QoL. Advanced stages are associated with lower performance status and serious side effects of the treatment.

QoL of patients with NSCLS looks to be influenced by gender, men reporting a better QoL than women with respect of social and emotional well-being [12], but in our study, no clinically significant difference between the two groups were encountered.

Referring to patient's age, literature data are contradictory, some reports proving lower scores in QoL of older patients and other showed the contrary, thatelderly patients have a better QoL $[4,12,13]$. In our study, we found a better score in social/family-well being scale for younger 
people and no other clinically significant difference, compared with older patients.

We also did not find any difference between smokers and non-smoker concerning QoL, although there are studies that showed a lower QoL in smokers [13-14]

An important issue influencing the QoL of NCSLC patients is the stage of the disease. Worse QoL of patients with other digestive types of cancer is reported to be associated in advanced stages at the time of diagnosis [15]. In the same manner, our study showed that advanced stages are associated with lower scores in all FACT-G scales.

Patients performance status is influencing all the subscales score from physical well-being to functional well-being and also the total score of FACT-G, meaning that our results look similar with literature data, showing that the better performance status means better patient QoL.

Referring to treatment, we found no significant difference in FACT-G score in patients receiving radiotherapy or chemotherapy, although some studies showed a negative impact on QoL under chemotherapy, additionally worsened by the significant number of chemotherapy cycles [16-18].

Concerning surgical therapy, a clinically significant difference was found in patients with NSCLC in terms of emotional-well being subscale score and FACT-G total score. Data reported by other authors also show an improvement in QoL of the NSCLC patients after surgery $[19,20]$.

\section{Conclusions}

Cancer stage and general performance status were found to be the primary determinants on QoL of our NSCLC patients. Symptoms as pain, dyspnea, and fatigue, limit the challenge to improve the QoL in pulmonary cancer patients. To improve the QoL in these clinical situations, there is of significant importance to identify all the factors that influence. We found in our study no clinical significance between QoL scores with respect with chemotherapy protocol or the number of cycles of chemotherapy. QoL and offer social, psychological and spiritual support to these patients to reduce the negative impact of the disease.

\section{References}

1.SIEGEL, R.L., MILLER, K.D, J EMAL, A., Cancer J . Clin. 68, 2018, p 7. 2.LIAO, Y.C., SHUN, S.C., LIAO, W.Y., YU, C.J., YANG, P.C., LAI, Y.H., Oncol.Nurs Forum, 41,nr.2, 2014, p.44-55.

3.ZIMMERMANN, C., BURMAN, D., SWAMI, N., et al., Support Care Cancer, 19,nr.5, 2011, p 621.

4.*** WORLD HEALTH ORGANIZATION: WHO Chron, 1947, 1, p 29. 5.SPITZER, W.O., DOBSON, A.J., HALL, J., et al., J. Chronic Dis., 34, $1981, \mathrm{p} 585$.

6.BROWN, D.J ., MCMILLAN, D.C., MILROY, R., Cancer, 103,nr.2, 2005, p 377.

7.CELLA, D.F., ETON, D.T., FAIRCLOUGH, D.L., BONOMI, P., HEYES, A.E., SILBERMAN, C., WOLF, M., JOHNSON, D., J. Clin. Epidemiol., 55,2002, p 285

8.CELLA, D.,TULSKY, D. S., GRAY, G., SARAFIAN, B., LINN, E., BONOMI, A., et al. J ournal of Clinical Oncology, 11,nr.3, 1993, p 570.

9.LOVGREN, M., TISHELMAN, C., SPRANGERS, M., KOYI, H., HAMBERG, K., Lung Cancer, 60,nr.1, 2008, p 113.

10.NISIPEANU, S.E., PECE,S.,IVAN, I.M. et al.,Environmental Engineering And Management J ournal,13,nr.6,2014,p.1537-1541

11.PARASCHIV, B., TOMA, C.L., DIACONU, C.C., Archivos de Bronconeumología,49,nr.7, 2013,p.315-316.

12.HERMANN, C.P., LOONEY, S.W., Oncol.Nurs. Forum, 38,nr.1, 2011, p 23.

13.RAVASCO, P., MONTEIRO-GRILLO,I., VIDAL, P.M., et al., Support Care Cancer, 12,nr.4, 2004 p 246.

14.POIANA,C. , NEAMTU, M.C, AVRAMESCU, E.T. et al., Romanian Journal Of Morphology And Embryology, 54,nr.3,S,2013,p.717-720

16.KARCZMAREK-BOROWSKA, B., PELC, M., RABIEJ , E., GRADALSKALAMPART, M., Pneumonol. Alergol. Pol., 82,nr.4, 2014, p 349.

17.LANGENDIJK, J. A., AARONSON, N. K., DE JONG, J .M.A., TEN VELDE, G.P.M., MULLER, M. J., LAMERS, R. J. ,SLOTMAN, B. J.,WOUTERS, E.F.M., J ournal of Clinical Oncology, 19,nr.8, 2001, p 2123.

18. GHEORGHIU,M.L., GALOIU,S., VINTILA,M., PURICE,M., HORTOPAN, D., DUMITRASCU, A.COCULESCU, M.,POIANA,C., Hormones-International Journal of Endocrinology And Metabolism,15,nr.2,2016,p.224-234.

19.STEFANESCU,D.C.,CEACHIR,O.,ZAINEA,V.et al., Rev. Chim. (Bucharest), 67,no.7,2016,p.1327-1328

20.WIN, T., SHARPLES, L., WELLS, F.C., RITCHIE, A.J., MUNDAY, H., LAROCHE, C.M., Thorax, 60,nr.3, 2005, p 234.

Manuscript received: 26.09 .2018 